\title{
Mechanical Properties of Corner Joints Made of Honeycomb Panels with Double Arrow-Shaped Auxetic Cores
}

\author{
Adam Majewski ${ }^{1, *(D)}$, Tomasz Krystofiak ${ }^{2}$ and Jerzy Smardzewski ${ }^{1}$ (D) \\ 1 Department of Furniture Design, Faculty of Forestry and Wood Technology, \\ Poznan University of Life Sciences, 60-637 Poznań, Poland; jerzy.smardzewski@up.poznan.pl \\ 2 Department of Wood Based Materials, Faculty of Forestry and Wood Technology, \\ Poznan University of Life Sciences, 60-637 Poznań, Poland; tomasz.krystofiak@up.poznan.pl \\ * Correspondence: adam.majewski@up.poznan.pl
}

Received: 12 August 2020; Accepted: 17 September 2020; Published: 22 September 2020

\begin{abstract}
The development of both light and strong wood-derived materials is an interesting research area, particularly in terms of usability in, e.g., furniture constructions. Honeycomb panels being current industry standard are relatively thick (32 $\mathrm{mm}$ and $40 \mathrm{~mm}$ ), thus their attractiveness in designing furniture is limited. In a few studies, it has been shown that honeycomb panels with paper cores are characterized by unsatisfactory mechanical properties, especially when the composite thickness is less than $20 \mathrm{~mm}$. From the literature, it is also evident that mechanical properties might be improved by introducing auxetic features into the core structure. Even though it is a concept with great potential, there are a few studies dealing with honeycomb panels with auxetic cores made of paper. Furthermore, there is no research on the corner joints made from such material. For this reason, the aim of the study was to test the bending behavior of the corner adhesive joints made of honeycomb panels with double arrow-shaped auxetic cores. Within the research, the core cell was adopted based on literature and preliminary studies, paper auxetic cores were produced by the use of the designed and $3 \mathrm{~d}$ printed device, and joints stiffness and strength were calculated analytically based on the experiment results. Evaluated corner joints stiffness, both in compression and tension test, is greater for samples made of panels with designed auxetic cores. Surprisingly, in the analyzed range of elasticity, it was statistically proved that the values of joint stiffness coefficient K did not vary significantly between compared joints pairs.
\end{abstract}

Keywords: corner; joints; auxetic; honeycomb; stiffness; strength

\section{Introduction}

Crucial aspect in terms of use safety of construction with semirigid joints is the way that elements are assembled. The role of joints is to provide construction, e.g., like furniture, with high rigidity and strength [1]. Before the influence of materials and technologies of joints quality were widely described, the analytical calculations of global furniture stiffness had been formulated [2-4]. Mathematical models from previous decade relate to specific joints' factors connected with numerical simulations of furniture rigidity [5-8]. Finite elements method (FEM), which has its origins in 1967, was interesting to use in studies on furniture joints rigidity undertaken by many authors [9-17]. Mechanical properties of corner joints for furniture purposes have been reported by many authors extensively. It is worth mentioning that vast majority of studies involve commonly used wood-derived materials, such as particleboard (PB) or medium density fiberboard (MDF) and additional items like fittings, adhesives, edge banding, or wooden add-ons. From the literature analysis, it is evident that in terms of corner joints rigidity, researchers used similar test methods and the following aspects were taken into account: 
- Influence of material density as well as stiffness and rigidity of fasteners. It is exposed in the literature that values of linear modulus of elasticity (MOE and MPa) are greater for joints made of materials with bigger densities and homogenous, nonporous structure. There are studies on joint strength by which number of construction forms were tested i.e., structural-adhesive (double dowel or lamello), conventional metal fasteners (screws and confirmats), and more innovative products from companies like Blum, Hafele, and Titus plus [18-32];

- Effect of number of fasteners on joint stiffness, which is greater when the joint contact surface is bigger. This tendency is proportional to the number of used fasteners [10,33-37];

- Influence of distribution of fasteners. For instance, for double dowel joint the most effective dowel distribution equals $96 \mathrm{~mm}$ [38-42];

- Influence of fastener/joint geometry on joint stiffness. The increase in fastener length and diameter results in joint strength improvement, although increasing length is more effective [6,36,43,44]. Material change as well as different walls inclination angle was taken into consideration in corner dovetail joint test. Among examined samples including 5 different inclination angle values $\left(75^{\circ}\right.$, $78^{\circ}, 81^{\circ}, 84^{\circ}$, and $87^{\circ}$ ), four types of materials (birch, oak, pine, and MDF) and two adhesives, polyvinyl acetate (PVAc) and Desmodur-VTKA (D-VTKA), the best option was oak with $84^{\circ}$ glued with D-VTKA [45];

- Presence, type, and adhesives application technique. In the literature, there are studies concerning diversity of adhesives, glue layer thickness, and gluing application methods. In general, the use of adhesives significantly improves joint strength [12,18,22,46-48]. Furthermore, better stiffness is a result of using silicon glue rather than PVAc [21];

- Effect of narrow surfaces finishing, use of edge banding, as well as its type and thickness. There are studies in the literature on the rigidity of furniture joints made of laminated PB and MDF. In addition, sides of samples were covered with: melamine edge band $0.4 \mathrm{~mm}$ thick, PVAc (0.4, 1, and $2 \mathrm{~mm}$ thick), and birch veneer (0.4, 1, and $2 \mathrm{~mm}$ thick) [49]. It was proved that the strongest joint was made of MDF with melamine edge banding. Average joint strength was about $17 \%$ and $18 \%$ better in comparison to the second-best variant (PB and PVAc, $0.4 \mathrm{~mm}$ ) in compression and tension tests, respectively. Fathollahzadeh et al. [50] subjected different types of furniture cases (made of laminated MDF and raw MDF in versions both with and without elements edging) to cyclic loading. It was found that the strength of construction elements with edging is 1.8 times higher;

- The effect of a fastener grain orientation changes in relation to the grain direction of the specimen on the pulled-out joint strength. The stress distribution in model consisting of a dowel embedded in a maple wood sample was checked numerically. The change in moisture content from $10 \%$ to $18 \%$ was simulated, and the direction of the dowel fibers was orientated at $0^{\circ}, 30^{\circ}, 60^{\circ}$, and $90^{\circ}$ in relation to the fiber direction of the sample. It was shown that the highest virtual pull-out strength was observed for the variant with $90^{\circ}$ [51];

- The influence of the back panel assembly method on the strength of the corner joints. The presence of the back panel significantly improves the strength of the connection. In one of the works, the assembly methods have been assessed, where a back panel was mounted by screws to $18 \mathrm{~mm}$ thick elements made of: raw PB, veneer-coated PB, plywood (PLY), and MDF. Back panels were installed directly and through wooden (birch) add-ons. In each case, the use of wooden add-ons increased the strength of the joint as a result of the screws being firmly embedded in the material [52];

- The influence of the fasteners mounting force on the joint strength. The numerical calculations have shown that the application of maximum force moment while screwing a confirmat-type fastener into PB does not cause it to crack along the thread. On the other hand, the board is damaged due to the pressure of the confirmat head [5]. In another work, different hinges mounting plates and drawer sliders assembly methods were tested: directly to the panels by Euro screws, wood screws and plastic muff, and wood screws and a mounting plate. Different torque values 
for screwing fasteners were taken into account. Based on the results, it was found out that the most advantageous way is to use screws with a muff and a force moment value of $1.342 \mathrm{Nm}$ [42];

- The effect of the guide holes diameter for screwed-in connectors on the joint strength. In order to increase the strength of joint, it is recommended to make guide sockets with diameters of $75-80 \%$ of the nominal diameter of the fastener [53-56].

In the light of presented literature overview, it must be stated that so far, there are only a few reports on mechanical properties of honeycomb panels with paper cores, although the idea of sandwich-like panels is generally known from 1960s [57]. However, some authors indicated their limits in the context of furniture industry utility [58-60]. They are mainly connected with relatively small MOE in comparison to standard materials for furniture production. Despite this fact, honeycomb panels remain tempting proposition as a more sustainable alternative for solid wood and research for their mechanical properties' improvement has been intensified in the course of past years. The use of light furniture elements, but with satisfactory strength, effects in increased mobility and significantly reduces the weight of a package with elements making both transportation and assembly more convenient. It is important, especially in the context of the phenomenon of ageing societies. Smardzewski and others [61] tested the influence of ambient temperature changes and air relative humidity on the stiffness of joints made of honeycomb panels with PB frames. It has been shown that increasing the values of these parameters results in the deterioration of joint stiffness by $25 \%$ and strength by $40 \%$. In Koreny's work [40], the analysis of the strength of honeycomb furniture joints was presented. Some of the fasteners for honeycombs that are available on the market were taken into account. It was shown that to achieve the best effect, fastener components should be glued in. After being embedded in the panel, their symmetrical axes should coincide. It was concluded that specified strength is acceptable for the broaden use of lightweight panels in furniture construction and remains consistent with their structural capabilities. Research should be continued, especially with regard to the shear strength of the embedded fasteners. The forementioned studies focus only on the hexagonal shape of the core cells and involve fasteners. From the literature, it is evident that mechanical properties of honeycomb panel may be modified by changing the size and height of a core cell, hence their relative density $[62,63]$. Therefore, more attention should be put to the research aimed at furniture honeycomb panel elastic properties improvement by changing these features on the basis of the auxetic materials concept, ergo with negative Poisson's ratio [64-66]. Numerous aspects of the auxetic structures application as well as their elastic constants have been already described in the literature [67-74]. However, there are a few studies on furniture honeycomb panels with auxetic core cells. Smardzewski [75] compared strength and MOE of panels with paper cores with both hexagonal and re-entrant cells. The overall panels' thickness was crucial, because unlike commonly known 32 or $40 \mathrm{~mm}$ thick composites, the research was based on 18 $\mathrm{mm}$ thickness. It was stated that panels with auxetic cores exposed increased mechanical properties, however honeycomb panels with two different orthotropy directions were analyzed. There is no information how the strength of panels differentiates when comparing results for samples with cores tested in both orthotropy directions. Some authors [76] also examined bending behavior of honeycomb panels with auxetic cores made of WoodEpox ${ }^{\circledR}$. Elastic characteristic, as well as amount of dissipated energy were taken into consideration. Among tested layered panels, the most favorable mechanical properties were exposed by honeycombs with facings prepared from high-density fiberboard-HDF and PLY, although as comes about the relationship between the MOE or Modulus of Rupture (MOR, $\mathrm{MPa}$ ) and the density of materials, the most effective was beam with PLY facings in longitudinal orthotropy direction. A wide spectrum of elastic constants was a result of the other research [77], in which honeycomb panels with lattice truss cores were tested. They were manufactured from biodegradable wood composite material-LayWood.

Summing up, based on a thorough literature review, it might be assumed that there are no studies regarding corner joints made of honeycomb panels with paper auxetic cores. Consequently, the potential use of such panels in the furniture construction has not been determined either, especially when their thickness is comparable to $18 \mathrm{~mm}$ PB or MDF. Bearing that in mind, it was decided 
to carry out research to determine the extent to which honeycomb panels with an auxetic cores affect the mechanical properties of a corner joint. Thus, the aim of the study was to evaluate the stiffness and strength of L-shaped joints incorporating both hexagonal (reference) and auxetic cores in joints compression and tension tests. To achieve results, it was necessary to firstly design auxetic core cell, develop production method of paper auxetic cores, prepare and test samples in terms of physical-mechanical properties of used materials, and then determine stiffness and strength of joints.

\section{Materials and Methods}

\subsection{Materials}

Materials used in the study were as follows: $2.5 \mathrm{~mm}$ thick HDF for facings; $0.18 \mathrm{~mm}$ thick craft paper for auxetic cores (grammage $118 \mathrm{~g} / \mathrm{m}^{2}$ ), which was cut in $12 \mathrm{~mm}$ width strips; a band of reference paper honeycomb $\left(0.18 \mathrm{~mm}\right.$ thick and grammage of $\left.120 \mathrm{~g} / \mathrm{m}^{2}\right)$ with hexagonal cell shape; a dispersion adhesive based on a vinyl acetate copolymer-Jowacoll 148.00 (Jowat SE, Detmold, Germany) for gluing paper strips into an auxetic double arrow-shaped core; $35 \mathrm{~mm}$ width particleboard frame slats calibrated to thickness of $11.7 \mathrm{~mm}$ for pressing panels sets; Racoll ECO 3 (Isar-Rakoll Chemie, Nienburg, Germany) adhesive based on PVAc for gluing panel sets consisting of facings (glue rate $100 \mathrm{~g} / \mathrm{m}^{2}$ ), frames, and cores; $2 \mathrm{~mm}$ thick acrylonitrile-butadiene-styrene copolymer (ABS) (Fritz Egger $\mathrm{GmbH} \&$ Co. OG, Weiberndorf, Austria) edge bands for 4 side covering narrow surfaces of joints elements; $1.75 \mathrm{~mm}$ polylactide (PLA) (3Dwydruki, Skórzewo, Poland) filament for 3D printing in Fused Deposition Modeling (FDM) technology for making the device used in auxetic core production process (3D printer-FlashForge Dreamer; FlashForge 3D Technology Co. Ltd., Jinhua, China); Jowat 2k SE Polymer 690.00 (Jowat SE, Detmold, Germany) —two-component silane-epoxide (SE) adhesive (glueline grammage $2.74 \mathrm{~g}$ ) for L-shaped corner joints preparation for compression and tension tests (only glue, no fasteners).

\subsection{Corner Joints Stiffness Calculation Method}

Two types of joint test were planned-compression (described as C) and tension (described as T). The calculation of the stiffness coefficient of corner joints was based on the method presented in the literature $[44,78]$. The advantage of this solution is the possibility to calculate analytically the value of the angle inclined between the elements instead of performing measurements using laboratory methods. Figure 1 illustrates the schemes on the basis of which equations were derived to determine the value of this angle in compressed and tensioned corner joints, as well as Zwick 1445 (Zwick Roell $\mathrm{GmbH}$ and Co.KG, Ulm, Germany) test machine with equipment used for the experiment.
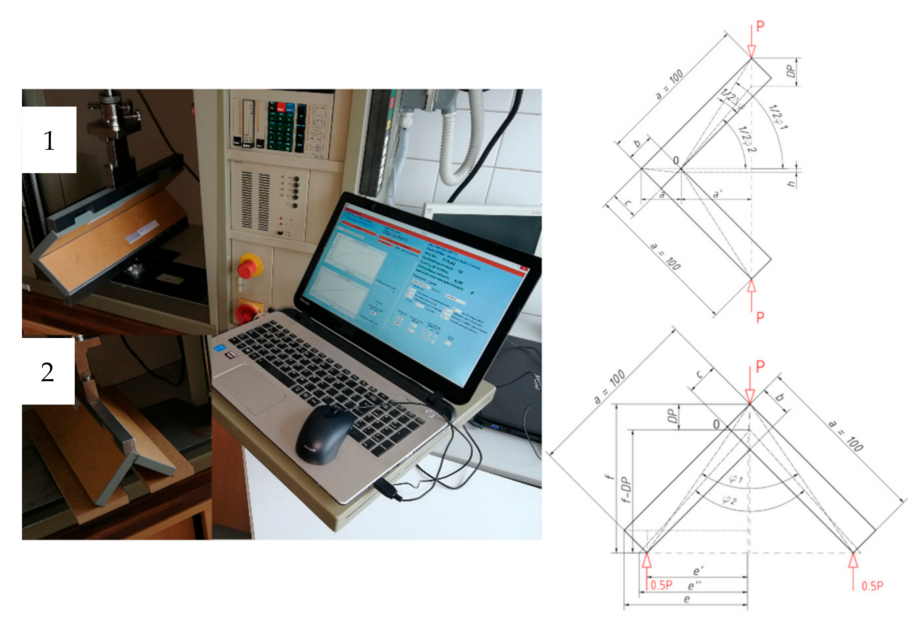

Figure 1. Zwick 1445 test machine and loading scheme for joint in (1) compression-C and (2) tension-T. 
Due to illustrated geometry, the stiffness coefficient $\mathrm{K}_{\mathrm{c}}$ in compression test was calculated as follows:

$$
\begin{gathered}
\mathrm{K}_{\mathrm{c}=} 0.4 P_{\max } a^{\prime} / \Delta \varphi[\mathrm{Nm} / \mathrm{rad}] \\
\Delta \varphi=\frac{\pi}{90}\left(\varphi_{1}-\varphi_{2}\right) \\
a^{\prime}=\frac{\sqrt{2}}{2} a-a^{\prime \prime} \\
a^{\prime \prime}=\sqrt{b^{2}+c^{2}-h^{2}} \\
h=\frac{\sqrt{2}}{2}(b-c) \\
\varphi_{1}=\operatorname{arctg}\left(\frac{\frac{\sqrt{2}}{2} a-h}{a^{\prime}}\right) \\
\varphi_{2}=\arcsin \left(\frac{\frac{\sqrt{2}}{2} a-h-D P_{0.4 P_{\max }}}{\sqrt{c^{2}+(a-b)^{2}}}\right)
\end{gathered}
$$

In the case of the corner joint tension test, the stiffness coefficient $\mathrm{K}_{\mathrm{t}}$ equation was:

$$
\begin{gathered}
\mathrm{K}_{\mathrm{t}}=0.4 P_{\max } e^{\prime \prime} / \Delta \varphi[\mathrm{Nm} / \mathrm{rad}] \\
\Delta \varphi=\frac{\pi}{90}\left(\varphi_{2}-\varphi_{1}\right) \\
e^{\prime}=\frac{\sqrt{2}}{2}(a-b) \\
0.5 \varphi_{1}=\operatorname{arctg}\left(\frac{e^{\prime}}{f}\right), \\
0.5 \varphi_{2}=\operatorname{arctg}\left(\frac{e^{\prime \prime}}{f-D P_{0.4 P_{\max }}}\right), \\
f=e+\frac{\sqrt{2}}{2} b \\
e^{\prime \prime}=\sqrt{e^{\prime 2}+f^{2}-\left(f-D P_{0.4 P_{\max }}\right)^{2} .}
\end{gathered}
$$

The above equations, in addition to the parameters suitable for the test type, take into account the values of: destructive force $\mathrm{P}_{\max }(\mathrm{N})$, the force is representing the conventional linear elastic limit $\mathrm{P}_{0.4 P \max }(\mathrm{N})$, and the corresponding displacement of $\mathrm{DP}_{0.4 \mathrm{Pmax}}(\mathrm{mm})$. They resulted from experiments performed on Zwick 1445 test machine setup as follows: test mode-bending with material destruction, speed of access to the material $10 \mathrm{~mm} / \mathrm{min}$, breaking force system $10 \mathrm{~N}$, test speed $10 \mathrm{~mm} / \mathrm{min}$, force measurement accuracy $0.01 \mathrm{~N}$, traverse displacement accuracy $0.01 \mathrm{~mm}$, and maximum displacement set to $20 \mathrm{~mm}$. The measurements were noted until the applied load drop of $50 \mathrm{~N}$ from the maximum force was observed. There was even load distribution to joint edge of $400 \mathrm{~mm}$.

\subsection{Corner Joints Rigidity Calculation Method}

The strength of the corner joints has been calculated as the maximum bending moments of the joints. In accordance with the literature and Figure 1, it was considered as $M_{c}=P_{\max }{ }^{*} a^{\prime}(N m)$ for compression and $\mathrm{M}_{\mathrm{t}}=\mathrm{P}_{\max }{ }^{*} \mathrm{e}^{\prime \prime}(\mathrm{Nm})$ for tension test. 


\section{Samples Preparation}

To carry out the assumed research, it was necessary to: develop the shape of an auxetic core cell, select the shape of a reference hexagonal core cell, prepare paper cores with auxetic characteristic and reference ones, and produce honeycomb panels from which beams for elastic properties testing (without edge banding) and joints elements (elements covered four-sided with a $2 \mathrm{~mm}$ ABS edge) were prepared.

\subsection{Core Cell Design}

Analytical descriptions of elastic properties of thin-walled cell structures with negative Poisson's ratio are known in the literature [75,79-81]. The general shape of the auxetic core cell Figure 2a) has been selected based on the studies [70,82], but exact dimensions were adopted as a result of the author's preliminary research, where elastic constants of a single cell were analyzed [17]. The shape of the reference cell was selected and measured (Figure $2 b$ ). The cell relative density was determined based on their 3D models made in Autodesk Inventor Professional 2018 software (Autodesk, Inc., San Rafael, CA, USA). The relative density of the auxetic cell was 0.067 , whereas the relative density of a hexagonal one was 0.033 (Figure 2c).

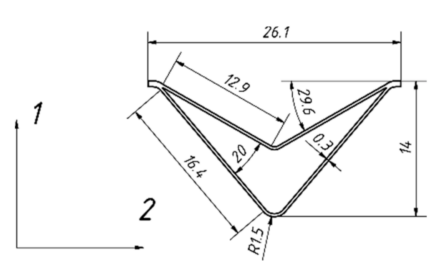

(a)

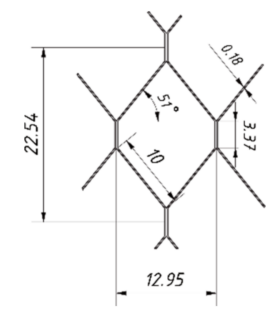

(b)

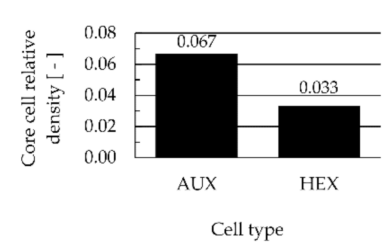

(c)

Figure 2. Tested core cells: (a) double arrow-shaped auxetic and (b) hexagonal and (c) relative density of cells.

\subsection{Cores and Honeycombs Preparation}

The description of cell arrangement in samples was adopted as HEX-1 and HEX-2, where HEX-1 and HEX-2 determines the direction of cell wall oriented parallel and perpendicular, respectively, to the longer side of the sample (Figure 3).

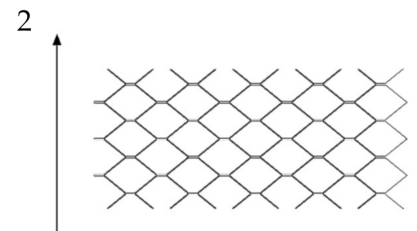

(a)

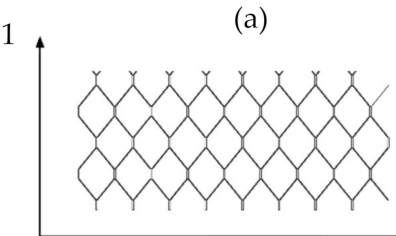

1

(c)

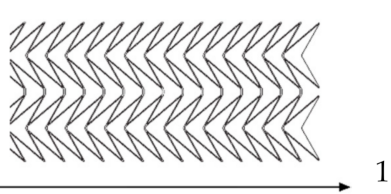

(b)

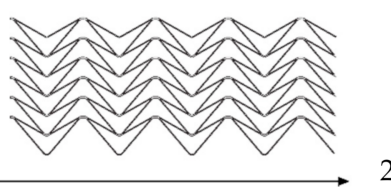

(d)

Figure 3. Orthotropy directions of panels: parallel for hexagonal HEX-1 (a) and auxetic cores AUX-1 (b) and perpendicular for hexagonal HEX-2 (c) and auxetic AUX-2 cores (d).

The preparation method of honeycomb cores with auxetic cells is shown in Figure 4a,g, whereas the way of manufacturing honeycomb panels including both types of cores is shown in Figure $4 \mathrm{~h}, \mathrm{k}$. 


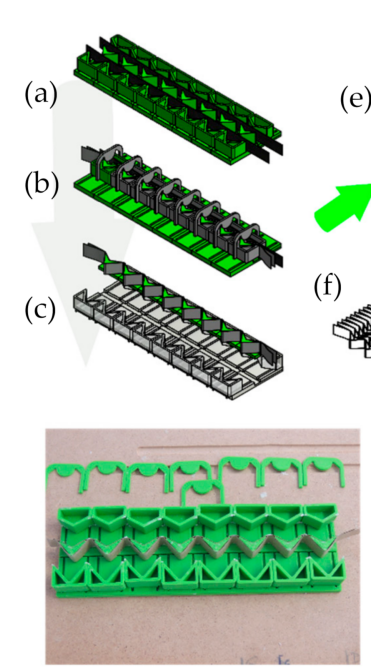

(d) (e)

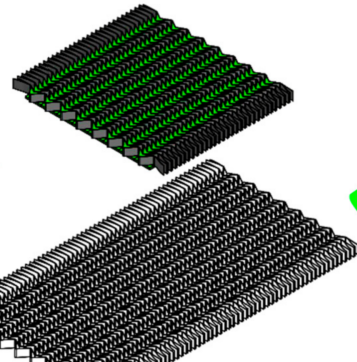

(i)

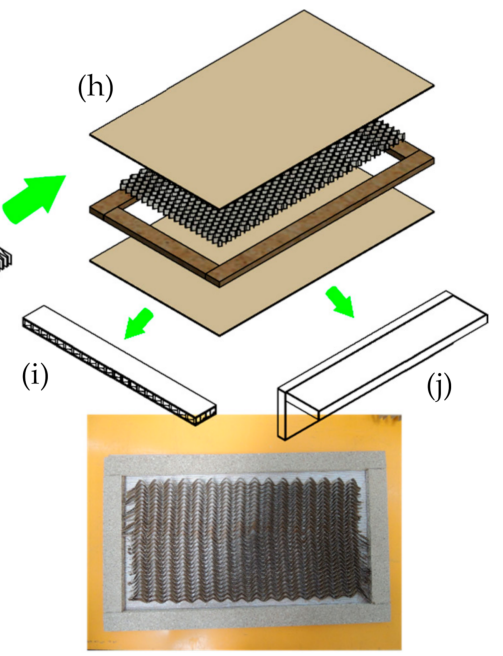

$(\mathrm{k})$

Figure 4. Honeycomb panels preparation method: paper strips were dragged along the designed and 3D printed device (a), then pressed successively by molds with simultaneous application of glue (b) to obtain a single slat with a row of core cells $(\mathbf{c}, \mathbf{d})$; then, 30 cell systems prepared in this way were glued in order to achieve the width of half of the assumed core dimension $(\mathbf{e}, \mathbf{g})$; after repeating the whole procedure, a paper core of the required dimensions of approximately $420 \times 230 \mathrm{~mm}^{2}$ (f) was obtained; then the cores (auxetic and reference) were embedded in $11.7 \mathrm{~mm}(\mathbf{k})$ particleboard frames, covered with $2.5 \mathrm{~mm} \mathrm{HDF}$ facings, and the sets $(\mathbf{h})$ were pressed $\left(\mathrm{p}=1 \mathrm{daN} / \mathrm{cm}^{2}, \mathrm{t}=10 \mathrm{~min}, \mathrm{~T}=20^{\circ} \mathrm{C}\right)$; approximately 100 panels were produced in this way-with auxetic and hexagonal reference cores, from which beams for three-point bending (i) and elements of corner joints (j) were cut out.

In total, 48 panels with auxetic cores, including both orthotropy directions were prepared. Dimensions of a single panel were $520 \times 317 \times 17 \mathrm{~mm}^{3}$.

\subsection{Corner Joints Preparation}

Cutting of the produced panels was carried out on the Felder K 700 Professional (Felder Group Polska Sp. z o.o., Żory, Poland) sawing machine. It was concluded that in order to stabilize the multilayered arrangement of the panels and to limit the delamination phenomenon in the early bending phase of the joints, the narrow surfaces of the samples should be covered on four sides with a $2 \mathrm{~mm}$ ABS edging. A HOMAG KFL 610 powerLine (HOMAG Group, Schopfloch, Germany) with Technomelt PUR 270/7 G (Henkel, Düsseldorf, Germany) polyurethane-based hot melt adhesive was used for this. Then, from the edge banded elements, the L-shaped joints intended for testing were made. It was crucial to prepare them in such a way that the contact surfaces of the elements could be considered as "perfectly rigid." This way, the stiffness of the tested joints can be assessed in terms of the stiffness of the panels, not the stiffness of the used fastener. The undertaken technological tests showed that the best method to achieve this is to use Jowat $2 \mathrm{k}$ SE Polymer 690.00 for adhesive bonding. According to the manufacturer's recommendations, full curing of the joint requires about 7 days of seasoning in normal conditions (temperature $23 \pm 2{ }^{\circ} \mathrm{C}$ and air humidity $50 \pm 5 \%$ ).

Eventually, bearing in mind the factors such as two test variants, two types of paper cores (auxetic and hexagonal), and two directions of core orthotropy, adequate samples were prepared, as shown in Table 1. Therefore, it was decided to use the ANOVA for further statistical analysis empowered by the Tukey's honest significant difference (HSD) test for pairs of means comparison (in case of joints stiffness) and Student's $t$-test for significance assessment of independent samples (in case of joints strength). Each corner joint consisted of two elements with dimensions: $400 \times 83 \times 17 \mathrm{~mm}^{3}$ and $400 \times 100 \times 17 \mathrm{~mm}^{3}$. The size of beams for bending was adopted according to standard [83]. It is worth mentioning that panels in HEX-2 core orientation are hardly present in industry practice. 
Table 1. Summary of samples prepared for tests.

\begin{tabular}{cccc}
\hline Test Type & Sample Code & Number of Samples & Sample Dimensions mm $^{\mathbf{3}}$ \\
\hline Beam 3-point bending & HEX-1 & 10 & $410 \times 50 \times 17$ \\
& HEX-2 & 10 & $410 \times 50 \times 17$ \\
& AUX-1 & 10 & $410 \times 50 \times 17$ \\
Joint compression test & AUX-2 & 10 & $410 \times 50 \times 17$ \\
& C-HEX-1 & 10 & $400 \times 100 \times 100$ \\
& C-HEX-2 & 5 & $400 \times 100 \times 100$ \\
& C-AUX-1 & 10 & $400 \times 100 \times 100$ \\
Joint tension test & C-AUX-2 & 10 & $400 \times 100 \times 100$ \\
& T-HEX-1 & 10 & $400 \times 100 \times 100$ \\
& T-HEX-2 & 5 & $400 \times 100 \times 100$ \\
& T-AUX-1 & 10 & $400 \times 100 \times 100$ \\
& T-AUX-2 & 10 & $400 \times 100 \times 100$ \\
\hline
\end{tabular}

\section{Results and Discussion}

\subsection{Materials and Panels Properties}

Mechanical properties of the paper used in the study in the machine (MD) and transverse (CD) orthotropy directions were determined in a tensile test in accordance with [84] using a Zwick 1445 machine and digital image analysis equipment (Digital Image Correlation-DIC). The measuring set consisted of a Dantec Dynamics KL50108 (Dantec Dynamics A/S, Skovlunde, Denmark) camera connected to a computer and Istra 4D 4.4.6.319 software. The MOE and MOR of HDF as well as manufactured multilayered panels were determined in accordance with [83]. For the HDF samples, the presence of adhesive located on the top (US) and bottom (LS) side of each sample was additionally considered. The moisture content of HDF facings [85], paper grammage [86], and paper thickness [87] were tested. The results of the physical-mechanical properties of materials and manufactured panels are recalled in Tables 2 and 3, respectively. Their detailed analysis, including statistical tests, is presented in author's other research [88]. As a result, panels thickness was as follows: AUX-1$17.05 \mathrm{~mm}(\mathrm{SD}=0.10 \mathrm{~mm})$, AUX-2-17.07 mm (SD = 0.11 mm), HEX-1-17.17 mm $(\mathrm{SD}=0.17 \mathrm{~mm})$, and HEX 2-17.04 $\mathrm{mm}(\mathrm{SD}=0.04 \mathrm{~mm})$.

Table 2. Physical and mechanical properties of materials used in the study [88].

\begin{tabular}{|c|c|c|c|c|c|}
\hline \multicolumn{3}{|c|}{ Paper } & \multicolumn{3}{|c|}{ HDF } \\
\hline Property & $\mathrm{MPa}$ & SD & Property & MPa & SD \\
\hline $\mathrm{MOE}_{\mathrm{MD}}$ & 2236 & 389 & MOE $_{\text {US }}$ & 4017 & 150 \\
\hline $\mathrm{MOE}_{\mathrm{CD}}$ & 692 & 156 & $\mathrm{MOE}_{\mathrm{LS}}$ & 3945 & 341 \\
\hline MOR $_{M D}$ & 13 & 2 & MOR $_{\text {US }}$ & 42 & 2 \\
\hline MOR $_{C D}$ & 5 & 1 & MOR $_{L S}$ & 39 & 4 \\
\hline $\mathrm{G}_{\mathrm{MD} / \mathrm{CD}}$ & 873 & - & $\mathrm{G}_{\mathrm{US} / \mathrm{LS}}$ & 1762 & - \\
\hline $\mathrm{G}_{\mathrm{CD} / \mathrm{MD}}$ & 291 & - & & & \\
\hline \multicolumn{3}{|c|}{-} & \multicolumn{3}{|c|}{-} \\
\hline$v_{\mathrm{MD} / \mathrm{CD}}$ & 0.28 & 0.07 & $v_{\mathrm{US} / \mathrm{LS}}$ & 0.28 & - \\
\hline$v_{\mathrm{CD} / \mathrm{MD}}$ & 0.19 & 0.06 & & & \\
\hline
\end{tabular}


Table 3. Physical and mechanical properties of tested honeycomb panels [88].

\begin{tabular}{cccc}
\hline \multirow{2}{*}{ Property } & MOE & MOR & $\rho_{\mathbf{r}}$ \\
\cline { 2 - 4 } & \multicolumn{3}{c}{$\mathbf{M P a}$} \\
\hline AUX-1 & 1381 & 3.8 & $\mathbf{k g} \mathbf{m}^{\mathbf{3}}$ \\
\hline SD & 83 & 0.2 & 400.3 \\
\hline AUX-2 & 1852 & 8 & 296.9 \\
\hline SD & 47 & 0.8 & 3.5 \\
\hline HEX-1 & 2025 & 8.7 & 284.6 \\
\hline SD & 85 & 0.4 & 5.1 \\
\hline HEX-2 & 1394 & 3.9 & 276.1 \\
\hline SD & 83 & 0.3 & 2.2 \\
\hline
\end{tabular}

Based on cited results, it can be seen that bigger MOE values had panels with cores in which common cell walls (glued together creating double-wall arrangement) were oriented perpendicular to the longer side of the sample. A similar tendency was expected to appear in terms of tested corner joints. Therefore, further results analysis was focused mainly on the comparison of pairs AUX-1: HEX-2 and AUX-2:HEX-1.

\subsection{Corner Joints Stiffness}

It should be noted that the two-component SE adhesive Jowat 2k SE Polymer 690.00 used for joints preparation generated a durable and resilient bonding. This resulted in achieving relatively big maximum forces, which only caused the joint deflection without any visible damage of the top layers of bonded surfaces. Figure 5 shows the average stiffness of the corner joints in the compression test.

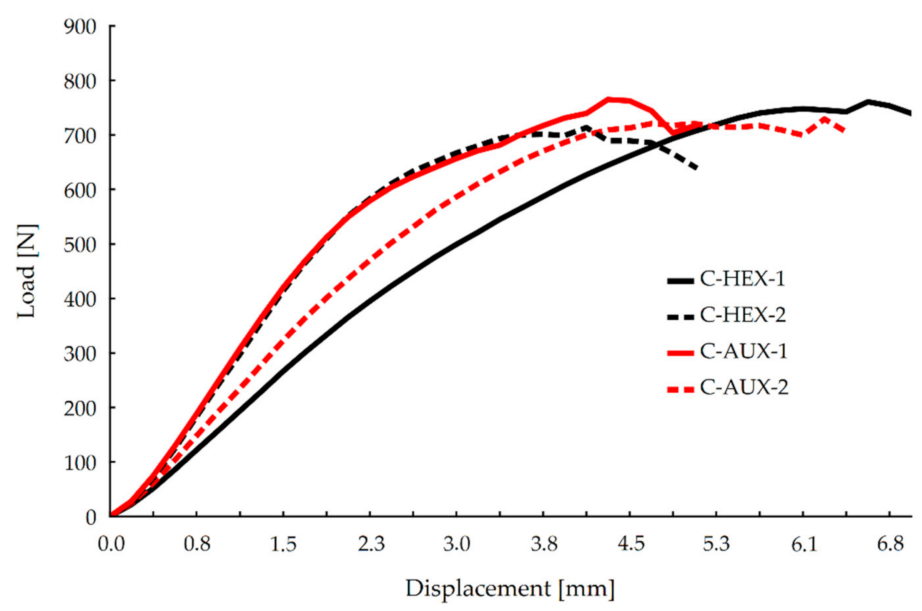

Figure 5. Stiffness of joints in the compression test.

It may be seen in this figure that all the compressed joints reached a maximum force of value $700 \mathrm{~N}$ and more. It can also be stated that stiffness of HEX-2 and AUX-1 nearly overlaps almost through the test, although after reaching deflection of $4 \mathrm{~mm}$, AUX-1 joints gain bigger maximum force (about $800 \mathrm{~N}$ ). In the displacement range of $2.3-4 \mathrm{~mm}$, the average difference in the force value is $84.5 \mathrm{~N}$. Relatively the biggest displacement increase with the smallest force increase was shown by HEX-1 type joints. In order to determine more precisely the stiffness of the joints in compression test, it was decided to focus on stiffness curves in the linear range of elasticity. It was found that for the value of the force equal to $40 \%$ of the destructive force $P_{\max }$, the limit of this range runs with a deflection of 
$1.5 \mathrm{~mm}$. Then, for each joints type, linear regression was adjusted, and its equation was calculated, as shown in Figure 6.

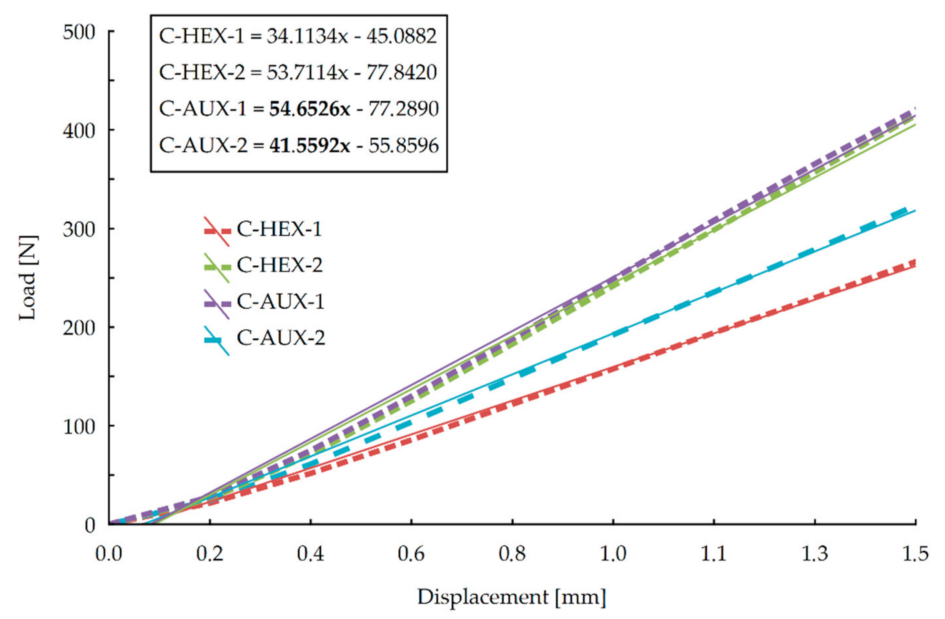

Figure 6. Stiffness of joints in compression test in the linear elasticity range.

On the basis of linear regression equations, it can be concluded that the directional coefficients of function have more significant values in the case of joints made of panels with auxetic cores, both in 1 and 2 orthotropic directions. There is a more significant difference between HEX-1 and AUX- 2 joints than HEX-2 and AUX-1. Therefore, from this analysis, it follows that joints with auxetic cores exhibit greater rigidity in the compression test. An analogous evaluation was carried out for the results of joints in the tension test (T) (Figure 7).

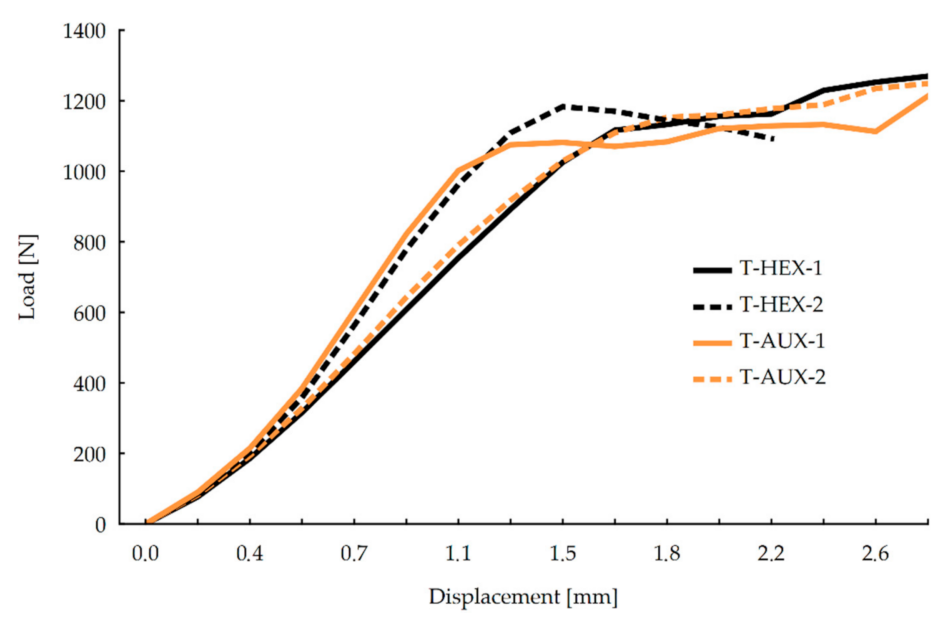

Figure 7. Stiffness of joints in the tension test.

It may be noticed that in the displacement range of $0-1.2 \mathrm{~mm}$, the averaged stiffness curves of HEX- 1 and AUX-2 as well as HEX-2 and AUX- 1 joints have similar courses. In the case of HEX-1 and AUX-2, it is only from a displacement of approximately $2.2 \mathrm{~mm}$ that the curves differ-the HEX-1 shows a slightly higher average stiffness at the end of the test. For the HEX-2 and AUX-1 joints, the difference occurred at twice the displacement value, i.e., approximately $1.1 \mathrm{~mm}$. In the $1.3-2 \mathrm{~mm}$ range, the stiffness of AUX-1 is slightly less than of HEX-2. In order to obtain a more complete description of the tensioned joints stiffness, it was decided to carry out an evaluation of matched linear regressions, as it was done in the evaluation of stiffness characteristics of the previous test, respectively. In this case, however, it was found that the range of linear elasticity is within the displacement range of $0-0.7 \mathrm{~mm}$, as shown in Figure 8. 


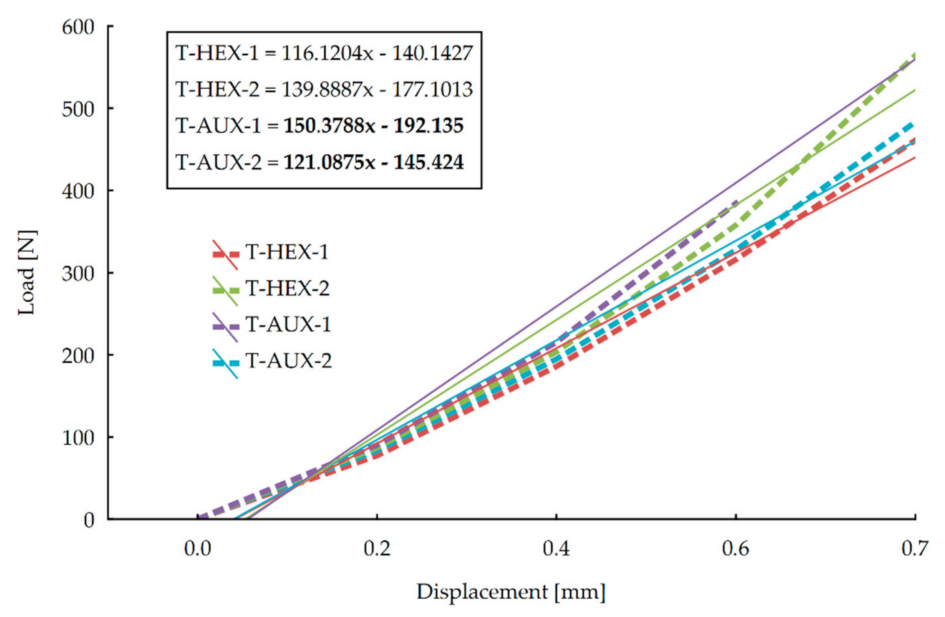

Figure 8. Stiffness of joints in tension test in the linear elasticity range.

It is clear that similar to the compression test results, greater directional coefficients of regressions show the joints made of panels with auxetic cores. Thus, it can be concluded that in the case of tensioned joints, those with auxetic cores exhibit better stiffness for both directions of orthotropy.

The above observations concerning the results of corner joints tests should be reflected in the determined stiffness coefficient $\mathrm{K}$. Therefore, Figure 9 presents the calculated values.

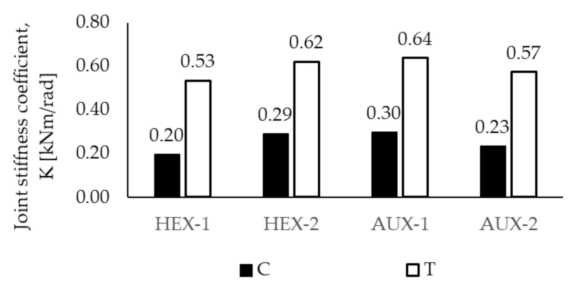

Figure 9. Stiffness coefficient $\mathrm{K}$ of corner joints in compression (C) and tension (T) test.

It is evident that slightly bigger values of the stiffness coefficient, for both tests, resulted for corner joints made of panels with auxetic cores. The differences are as follows:

- For compression test: the stiffness coefficient of AUX-2 is $15 \%$ bigger than HEX-1 and AUX- 1 is $3.4 \%$ bigger than HEX-2;

- For tension test: AUX-2 is 7.5\% stiffer than HEX-1 and AUX-1 is 3.2\% stiffer than HEX-2.

When evaluating the differences between the directions of core orthotropy in the samples, it can be observed that:

- The compressed AUX-1 joints expose a stiffness coefficient of 30.4\% bigger than AUX-2, although the tensioned AUX-1 joints show a stiffness coefficient of $12.3 \%$ bigger than AUX-2;

- The compressed joints HEX-2 have a $45.0 \%$ bigger stiffness coefficient $K$ than HEX-1, and tensioned HEX-2 show a stiffness coefficient of $17.0 \%$ bigger than HEX 1 .

In addition, the stiffness coefficient $\mathrm{K}$ obtained for compressed joints is in the case of:

- HEX-1 by $165 \%$,

- HEX-2 is $138 \%$,

- AUX-1 by $133 \%$,

- AUX-2 is $148 \%$ bigger than the value calculated for tensioned joints. 
Then the obtained results had to be verified by statistical analysis of ANOVA variance for the factor systems. In the first step, a one-dimensional significance test for stiffness coefficient $\mathrm{K}$ was carried out (Table 4).

Table 4. One-dimensional significance test for K coefficient $(\mathrm{kNm} / \mathrm{rad})$.

\begin{tabular}{|c|c|c|c|c|c|}
\hline Effect & SS & Degrees & MS & $F$ & $\mathrm{p}$ \\
\hline Free & $8,703,039$ & 1 & $8,703,039$ & $4,560,449$ & $0,000,000$ \\
\hline TT & $1,326,762$ & 1 & $1,326,762$ & 695,232 & $0,000,000$ \\
\hline CT & $0,002,946$ & 1 & $0,002,946$ & 1544 & $0,218,916$ \\
\hline $\mathrm{O}$ & $0,005,477$ & 1 & $0,005,477$ & 2870 & $0,095,441$ \\
\hline $\mathrm{TT}^{*} \mathrm{CT}$ & $0,000,031$ & 1 & $0,000,031$ & 0016 & $0,899,017$ \\
\hline $\mathrm{TT}^{*} \mathrm{O}$ & $0,000,012$ & 1 & $0,000,012$ & 0006 & $0,937,948$ \\
\hline $\mathrm{CT}^{*} \mathrm{O}$ & $0,082,873$ & 1 & $0,082,873$ & 43,426 & $0,000,000$ \\
\hline $\mathrm{TT}^{*} \mathrm{CT}^{*} \mathrm{O}$ & $0,000,782$ & 1 & $0,000,782$ & 0410 & $0,524,591$ \\
\hline Error & $0,114,502$ & 60 & $0,001,908$ & & \\
\hline
\end{tabular}

Results presented in Table 3 indicate that among the effects taken into account, the stiffness of joints is influenced by the type of joint test and the interaction of the core type with the directions of orthotropy. Therefore, it was decided to trace these relations by determining the tendency of stiffness coefficient change for honeycomb panels joints with hexagonal (HEX) and auxetic (AUX) cores to the test type (TT) and orthotropic directions (O). The result is shown in Figure 10.

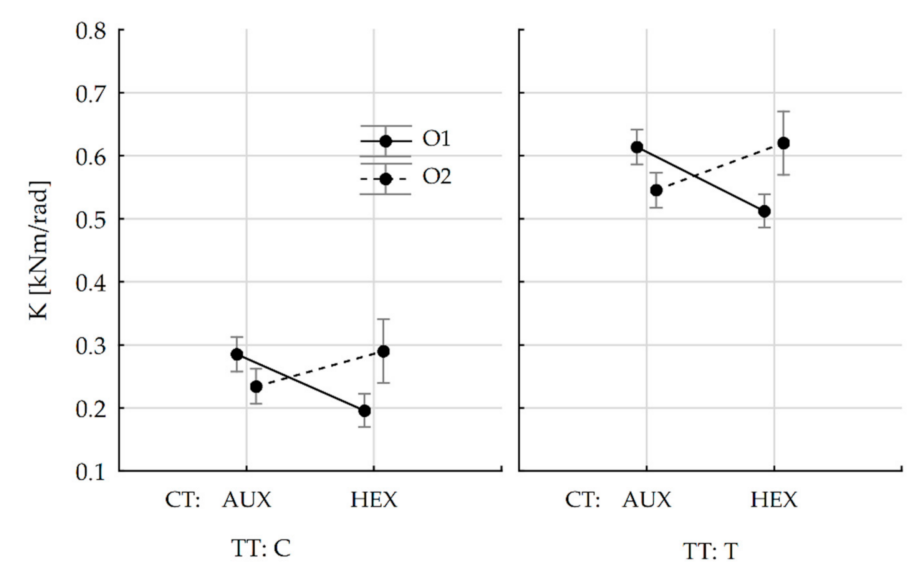

Figure 10. Change in stiffness coefficient depending on core type (CT) and orthotropy direction (O) and also type of joint test (TT) (vertical bars mean 0.95 confidence intervals).

It can be seen that for the orthotropic direction 2, the $\mathrm{K}$ coefficient is bigger in both tests and joints with hexagonal cores show slightly bigger stiffness. For the orthotropic direction 1, the trend is reversed and the change is more marked in both tests in favor of honeycomb panels joints with the auxetic cores. It was, therefore, necessary to determine whether the results presented in the graph are statistically different. Tukey's HSD test was then carried out for the K variable (Table 5). All the statistical computations were performed with the Statistica 13.1 software (StatSoft Polska Sp. z o.o., Kraków, Poland). 
Table 5. Tukey's HSD test for K variable (Nm/rad).

\begin{tabular}{|c|c|c|c|c|c|c|c|c|c|c|c|}
\hline & \multirow[b]{3}{*}{ TT } & \multirow[b]{3}{*}{ CT } & \multirow{3}{*}{$\begin{array}{l}\mathrm{TT} \\
\mathrm{CT} \\
\mathrm{O}\end{array}$} & \multicolumn{4}{|c|}{$\mathrm{C}$} & \multicolumn{4}{|c|}{$\mathrm{T}$} \\
\hline & & & & \multicolumn{2}{|c|}{ AUX } & \multicolumn{2}{|c|}{ HEX } & \multicolumn{2}{|c|}{ AUX } & \multicolumn{2}{|c|}{ HEX } \\
\hline & & & & 1 & 2 & 1 & 2 & 1 & 2 & 1 & 2 \\
\hline 1 & $\mathrm{C}$ & AUX & 1 & $x$ & 0.17299 & 0.00054 & 1.00000 & 0.00013 & 0.00013 & 0.00013 & 0.00013 \\
\hline 2 & $C$ & AUX & 2 & 0.17299 & $x$ & 0.48487 & 0.52762 & 0.00013 & 0.00013 & 0.00013 & 0.00013 \\
\hline 3 & $C$ & HEX & 1 & 0.00054 & 0.48487 & $x$ & 0.03181 & 0.00013 & 0.00013 & 0.00013 & 0.00013 \\
\hline 4 & $C$ & HEX & 2 & 1.00000 & 0.52762 & 0.03181 & $\mathrm{x}$ & 0.00013 & 0.00013 & 0.00013 & 0.00013 \\
\hline 5 & $\mathrm{~T}$ & AUX & 1 & 0.00013 & 0.00013 & 0.00013 & 0.00013 & $x$ & 0.01850 & 0.00016 & 1.00000 \\
\hline 6 & $\mathrm{~T}$ & AUX & 2 & 0.00013 & 0.00013 & 0.00013 & 0.00013 & 0.01850 & $x$ & 0.65786 & 0.17826 \\
\hline 7 & $\mathrm{~T}$ & HEX & 1 & 0.00013 & 0.00013 & 0.00013 & 0.00013 & 0.00016 & 0.65786 & $x$ & 0.00794 \\
\hline 8 & $\mathrm{~T}$ & HEX & 2 & 0.00013 & 0.00013 & 0.00013 & 0.00013 & 1.00000 & 0.17826 & 0.00794 & $x$ \\
\hline
\end{tabular}

Based on Tukey's test's results, it should be determined that the K-values of the joints pairs:

- In compression test: AUX-2:HEX-1 and AUX-1:HEX-2 do not differ significantly;

- In tension test: AUX-2:HEX-1 and AUX-1:HEX-2 do not differ significantly.

To sum up, the analysis of stiffness of the tested joints shows that in the range of linear elasticity, the linear regression curves for the ones with auxetic cores have bigger directional coefficients than the regressions of references with hexagonal cores. Stiffness coefficients of the former mentioned joints exposed bigger values, however, statistical analysis showed that these results do not differ significantly.

\subsection{Corner Joints Strength}

Calculated corner joints strength is presented in Figure 11.

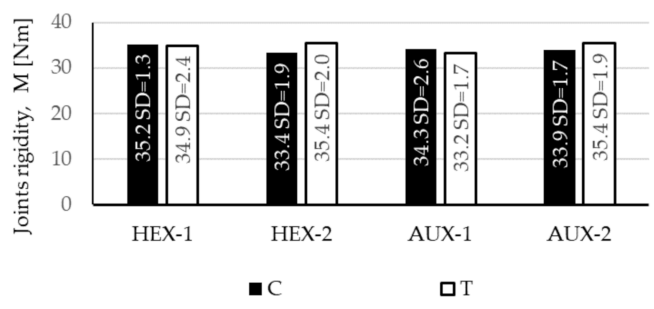

Figure 11. Rigidity of corner joints made of honeycomb panels in compression test (C) and tension test $(\mathrm{T})$.

The biggest strength of $35.4 \mathrm{Nm}$ was shown by the tensioned AUX-2 (SD $=1.9 \mathrm{Nm})$ and HEX-2 $(\mathrm{SD}=2.0 \mathrm{Nm})$ joints. This is $6.6 \%$ and $1.4 \%$ bigger than AUX-1 $(\mathrm{Mt}=32.2 \mathrm{Nm}, \mathrm{SD}=1.9 \mathrm{Nm})$ and HEX-1 $\left(\mathrm{M}_{\mathrm{t}}=34.9 \mathrm{Nm}, \mathrm{SD}=2.4 \mathrm{Nm}\right)$, respectively. The strength of the tensioned AUX-1 joints is at the same time the smallest of the obtained ones. The compression HEX-1 joints showed a strength of only $0.6 \%\left(\mathrm{M}_{\mathrm{c}}=35.2 \mathrm{Nm}, \mathrm{SD}=1.3 \mathrm{Nm}\right)$ less than the maximum values. This result is at the same time $5.4 \%$ bigger than the strength of compressed HEX-2 joints $\left(\mathrm{M}_{\mathrm{c}}=33.4 \mathrm{Nm}, \mathrm{SD}=1.9 \mathrm{Nm}\right)$. The compressed AUX-2 strength of $33.9 \mathrm{Nm}(\mathrm{SD}=1.7 \mathrm{Nm})$ is only $1.2 \%$ less than AUX-1 $(\mathrm{Mc}=34.3 \mathrm{Nm}, \mathrm{SD}=2.6 \mathrm{Nm})$. The joints strength seems to be very similar in both types of tests, as the biggest differences in values differ by several percentage points. Next, the Student's statistical $t$-test for independent samples was performed to verify the significance of these differences at a level of $p=0.05$. On the basis of the obtained results, it can be indicated that the values differ significantly when comparing the strength of joints: in compression test HEX-1 and AUX-2, compression HEX-1 and tension AUX-1, and tension AUX-1 and AUX-2. 


\section{Conclusions}

On the basis of the research, the following conclusions and observations were drawn:

It was characteristic that greater stiffness coefficient in both compression and tension tests was achieved by panels with cores in which common cell walls were oriented perpendicular to longer sample side, namely, AUX-1 (0.3 kNm in the compression test and $0.64 \mathrm{kNm}$ in tension test) and HEX-2 (0.29 kNm in compression and $0.62 \mathrm{kNm}$ in tension test) comparing to AUX-2 $(0.23 \mathrm{kNm}$ in the compression test and $0.57 \mathrm{kNm}$ in tension test $)$ and HEX-1 $(0.20 \mathrm{kNm}$ in the compression test and $0.53 \mathrm{kNm}$ in tension test). However, results of Tukey's test showed that values for compared joints pairs HEX-1:AUX-2 and HEX-2:AUX-1 do not differ significantly.

Between the compared pairs of joints, namely, AUX-2:HEX-1 and AUX-1:HEX-2, the average stiffness both in the compression and tension tests was slightly better in the case of panels with auxetic cores. Furthermore, in the range of linear elasticity, the directional coefficient of matched linear regressions showed a bigger value for joints made of panels with auxetic cores.

The use of double arrow-shaped auxetic cells, despite their double relative density compared to hexagonal reference cells, did not increase the modulus of linear elasticity. The mean MOE values of HEX-1 (2025 MPa, SD = $85 \mathrm{MPa})$ and AUX-2 (1852 MPa, SD = 47 MPa) panels differed significantly in favor of HEX-1, whereas for HEX-2 (1394 MPa, SD = $83 \mathrm{MPa})$ and AUX-1 (1381 MPa, SD = $83 \mathrm{MPa})$, the MOE values did not differ significantly. For this reason, cores with hexagonal cells remain attractive to be used for producing lightweight, layered furniture panels.

When it comes to the use of panels with auxetic cores, it is recommended to choose core orientation where glued common walls are arranged perpendicularly to the longer side of elements. These panels can be used in furniture structures, especially for horizontal partitions.

Author Contributions: Conceptualization, J.S. and A.M.; methodology, J.S. and A.M.; software, A.M.; validation, A.M., T.K., and J.S.; formal analysis, A.M.; investigation, A.M.; resources, A.M. and T.K.; data curation, A.M.; writing-original draft preparation, A.M.; writing-review and editing, J.S. and T.K.; visualization, A.M.; supervision, J.S.; project administration, J.S.; funding acquisition, A.M. All authors have read and agreed to the published version of the manuscript.

Funding: The paper was funded by the framework of the Ministry of Science and Higher Education programme "Regional Initiative of Excellence" in years 2019-2022, Project No. 005/RID/2018/19.

Conflicts of Interest: The authors declare no conflict of interest.

\section{References}

1. Smardzewski, J. Furniture Design; Springer: Cham, Switzerland, 2015.

2. Eckelman, C.A.; Suddarth, S.K. Analysis and design of furniture frames. Wood Sci. Technol. 1969, 3, $239-255$. [CrossRef]

3. Eckelman, C.A.; Rabiej, R. A comprehensive method of analysis of case furniture. For. Prod. J. 1985, 35, 62-68.

4. Eckelman, C.A.; Munz, S. Rational design of cases with front frames and semi-rigid joints. For. Prod. J. 1987, 37, 25-30.

5. Smardzewski, J.; Ozarska, B. Rigidity of cabinet furniture with semi-rigid joints of the confirmat type. Electron. J. Polish Agric. Univ. Ser. Wood Technol. 2005, 8, 32.

6. Tankut, A.N.; Tankut, N. Section modulus of corner joints in furniture frames as engineering design criteria for their efficient construction. Mater. Des. 2011, 32, 2391-2395. [CrossRef]

7. Smardzewski, J.; Lewandowski, W.; Imirzi, H.Ö. Elasticity modulus of cabinet furniture joints. Mater. Des. 2014, 60, 260-266. [CrossRef]

8. Smardzewski, J.; Prekrat, S. Stress Distribution in Disconnected Furniture Joints. Electron. J. Polish Agric. Univ. 2002, 5,4 .

9. Cai, L.; Yu, S.; Guo, X. The prediction of case furniture deflection. J. Northeast For. Univ. 1992, 3, 68-74.

10. Cai, L.; Fenghu, W. Influence of the stiffness of corner joint on case furniture deflection. Holz Roh Werkst. 1993, 51, 406-408. [CrossRef] 
11. Nicholls, T.; Crisan, R. Study of the stress-strain state in corner joints and box-type furniture using finite element analysis (FEA). Holz Roh Werkst. 2002, 60, 66-71. [CrossRef]

12. Smardzewski, J. Technological heterogeneity of adhesive bonds in wood joints. Wood Sci. Technol. 2002, 36, 213-227. [CrossRef]

13. Mostowski, R.; Sydor, M. Board Delamination With Edge Breakage As One of Failure Mechanisms in Semi-Rigid Corner Connections-Numerical Analysis. In Proceedings of the 47th International Conference of Departments of Design of Machine Elements and Mechanisms, Prague, Chech Republic, 13-15 September 2006.

14. Smardzewski, J.; Prekrat, S. Effect of Glueline Shape on Strength of Mortise and Tenon Joint Utjecaj oblika lijepljene površine na čvrstoću spoja rupe i čepa. Drv. Ind. 2010, 61, 223-228.

15. Smardzewski, J.; Kłos, R. Modeling of joint substitutive rigidity of board elements. Ann. Wars. Univ. Life Sci. SGGW For. Wood Technol. 2011, 73, 7-15.

16. Hajdarević, S.; Martinović, S. Effect of tenon length on flexibility of mortise and tenon joint. Procedia Eng. 2014, 69, 678-685. [CrossRef]

17. Smardzewski, J.; Majewski, A. Mechanical properties of auxetic honeycomb core with triangular cells. In Proceedings of the 25th International Scientific Conference: New Materials and Technologies in the Function of Wooden Products, Zagreb, Croatia, 17 October 2014; pp. 103-112.

18. Altinok, M.; Taş, H.H.; Çimen, M. Effects of combined usage of traditional glue joint methods in box construction on strength of furniture. Mater. Des. 2009, 30, 3313-3317. [CrossRef]

19. Altinok, M.; Tas, H.H.; Sancak, E. Load carrying capacity of spline joints as affected by board and adhesives type. Sci. Res. Essays 2009, 4, 479-483.

20. Eckelman, C.A.; Liu, W.-Q. Effect of number of fasteners on the strength of corner joints for cases. For. Prod. J. 1998, 48, 93-95.

21. Taş, H.H. Strength properties of L-profiled furniture joints constructed with laminated wooden panels. Sci. Res. Essays 2010, 5, 545-550.

22. Taş, H.H.; Altinok, M.; Çimen, M. The strength properties changing according to type corner joints and adhesive of the wood-based furnitures under the effect of dynamic forces. Wood Res. 2014, 59, 359-372.

23. Kureli, I.; Altinok, M. Determination of mechanical performances of the portable fasteners used on case furniture joints. Afr. J. Agric. Res. 2011, 6, 4893-4901. [CrossRef]

24. Arabi, M.; Faezipour, M.; Haftkhani, A.R.; Maleki, S. The effect of particle size on the prediction accuracy of screw withdrawal resistance (SWR) models. J. Indian Acad. Wood Sci. 2012, 9, 53-56. [CrossRef]

25. Vassiliou, V.; Barboutis, I. Bending strength of furniture corner joints constructed with insert fittings. Ann. Wars. Univ. Life Sci. SGGW. For. Wood Technol. 2009, 67, 268-274.

26. Atar, M.; Ozcifci, A.; Altinok, M.; Celikel, U. Determination of diagonal compression and tension performances for case furniture corner joints constructed with wood biscuits. Mater. Des. 2009, 30, 665-670. [CrossRef]

27. Çetin Yerlikaya, N.; Aktaş, A. Enhancement of load-carrying capacity of corner joints in case-type furniture. Mater. Des. 2012, 37, 393-401. [CrossRef]

28. Kasal, A.; Şener, S.; Mehmet Belgin, Ç.; Efe, H. Bending Strength of Screwed Corner Joints with Different Materials. Gazi Univ. J. Sci. 2010, 19, 155-161.

29. Tunay, M.; Tankut, N. Effect of various factors on the rigidity of furniture cases. Afr. J. Biotechnol. 2009, 8, 5265-5270. [CrossRef]

30. Korený, A.; Šimek, M. Experimental testing of cam fittings. Ann. Wars. Univ. Life Sci. SGGW. For. Wood Technol. 2011, 73, 51-59.

31. Vassiliou, V.; Barboutis, I. Screw withdrawal capacity used in the eccentric joints of cabinet furniture connectors in particleboard and MDF. J. Wood Sci. 2005, 51, 572-576. [CrossRef]

32. Tankut, A.N.; Tankut, N. Investigations the effects of fastener, glue, and composite material types on the strength of corner joints in case-type furniture construction. Mater. Des. 2009, 30, 4175-4182. [CrossRef]

33. Ho, C.L.; Eckelman, C.A. The Use of Performance Tests in Evaluating Joint and Fastener Strength in Case Furniture. For. Prod. J. 1994, 44, 47-53.

34. Tankut, A.N.; Tankut, N. The effects of joint forms (Shape) and dimensions on the strengths of mortise and tenon joints. Turk. J. Agric. For. 2005, 29, 493-498. [CrossRef]

35. Ozkaya, K.; Burdurlu, E.; Ilce, A.C.; Ciiitcioghi, H.H. Diagonal tensile strength of an oriented strand-board (OSB) frame with dovetail corner joint. BioResources 2010, 5, 2690-2701. [CrossRef] 
36. Kasal, A. Effect of the number of screws and screw size on moment capacity of furniture corner joints in case construction. For. Prod. J. 2008, 58, 36-44.

37. Malkoçoğlu, A.; Yerlikaya, N.Ç.; Çakiroğlu, F.L. Effects of number and distance between dowels of ready-to-assemble furniture on bending moment resistance of corner joints. Wood Res. 2013, 58, 671-680.

38. Eckelman, C.A. Bending strength and moment-rotation characteristics of two-pin moment resisting dowel joints. For. Prod. J. 1971, 21, 35-39.

39. Zhang, J.L.; Eckelman, C.A. Rational Design of Multi-Dowel Corner Joints in Case Construction. For. Prod. J. 1993, 43, 52-58.

40. Koreny, A.; Simek, M.; Eckelman, C.A.; Haviarova, E. Mechanical properties of knock-down joints in honeycomb panels. BioResources 2013, 8, 4873-4882. [CrossRef]

41. Simek, M.; Haviarova, E.; Eckelman, C. The effect of end distance and number of ready-toassemble furniture fasteners on bending moment resistance of corner joints. Wood Fiber Sci. 2010, 42, 92-98.

42. Smardzewski, J.; Majewski, A. Strength and durability of furniture drawers and doors. Mater. Des. 2013, 51, 61-66. [CrossRef]

43. Zhang, J.L.; Eckelman, C.A. The Bending Moment Resistance of Single-Dowel Corner Joints in Case Construction. For. Prod. J. 1993, 43, 19-24.

44. Smardzewski, J.; imirzi, H.Ö.; Lange, J.; Podskarbi, M. Assessment method of bench joints made of wood-based composites. Compos. Struct. 2015, 123, 123-131. [CrossRef]

45. Atar, M.; Keskin, H.; Peker, H.; Ustundag, A.; Togay, A.; Candan, Z. Impacts of different joint angles and adhesives on diagonal tension performances of box-type furniture. BioResources 2010, 5, 343-355.

46. Tout, R. Review of adhesives for furniture. Int. J. Adhes. Adhes. 2000, 20, 269-272. [CrossRef]

47. Norvydas, V.; Baltrušaitis, A.; Juodeikieno, I. Investigation of miter corner joint strength of case furniture from particleboard. Medziagotyra 2012, 18, 352-357. [CrossRef]

48. Altun, S.; Burdurlu, E.; Kiliç, M. Effect of adhesive type on the bending moment capacity of miter frame corner joints. BioResources 2010, 5, 1473-1483. [CrossRef]

49. Tankut, A.N.; Tankut, N. Evaluation the effects of edge banding type and thickness on the strength of corner joints in case-type furniture. Mater. Des. 2010, 31, 2956-2963. [CrossRef]

50. Fathollahzadeh, A.; Enayati, A.A.; Erdil, Y.Z. Effect of laboratory-accelerated aging treatment on the ultimate strength of a 4-sided MDF kitchen cabinet. Turk. J. Agric. For. 2013, 37, 649-656. [CrossRef]

51. Wang, Y.; Lee, S.H. Design and analysis on interference fit in the hardwood dowelglued joint by finite element method. Procedia Eng. 2014, 79, 166-172. [CrossRef]

52. Atar, M.; Özçifçi, A. The effects of screw and back panels on the strength of corner joints in case furniture. Mater. Des. 2008, 29, 519-525. [CrossRef]

53. Eckelman, C.A. The withdrawal strength of screws from Medium Density Fiberboard. For. Prod. J. 1988, 38, 21-24.

54. Erdil, Y.Z.; Zhang, J.; Eckelman, C.A. Holding strength of screws in plywood and oriented strandboard. For. Prod. J. 2002, 52, 55-62.

55. Tankut, N. The influence of pilot hole on the moment resistance of screwed T-Type furniture joints. For. Wood Technol. 2011, 84, 75-84.

56. Haftkhani, A.R.; Ebrahimi, G.; Tajvidi, M.; Layeghi, M.; Arabi, M. Lateral resistance of joints made with various screws in commercial wood plastic composites. Mater. Des. 2011, 32, 4062-4068. [CrossRef]

57. Seidl, R.J. Paper Honeycomb Cores for Structural Sandwich Panels—Report No. 1918; United States Department of Agriculture: Washington, DC, USA, 1956.

58. Barboutis, I.; Vassiliou, V. Strength properties of lightweight paper honeycomb panels for the furniture. 2005, p. 17. Available online: http://users.auth.gr/ jbarb/Publications/lightweight\%20honeycomb\%20furniture.pdf (accessed on 18 September 2020).

59. Smardzewski, J.; Majewski, A.; Prekrat, S. Effect of cell-wall angle on the uniaxial crushing behaviour of paper hexagonal honeycombs. In the 24th International Scientific Conference: Wood is Good-User Oriented Material, Technology and Design, Proceedings; Faculty of Forestry, Zagreb University: Zagreb, Croatia, 2013; pp. 127-136.

60. Petutschnigg, A.J.; Ebner, M. Lightweight paper materials for furniture - A design study to develop and evaluate materials and joints. Mater. Des. 2007, 28, 408-413. [CrossRef] 
61. Smardzewski, J.; Słonina, M.; Maslej, M. Stiffness and failure behaviour of wood based honeycomb sandwich corner joints in different climates. Compos. Struct. 2017, 168, 153-163. [CrossRef]

62. Sam-Brew, S.; Semple, K.; Smith, G.D. Preliminary experiments on the manufacture of hollow core composite panels. For. Prod. J. 2011, 61, 381-389. [CrossRef]

63. Xie, Y.; Yan, L.R. Experimental investigation into the static cushioning properties of rhombic honeycomb paperboard. Appl. Mech. Mater. 2011,55-57, 1299-1304. [CrossRef]

64. Smardzewski, J.; Prekrat, S. Auxetic structures in layered furniture panels. In Proceedings of the 29th International Conference Wood Science Technology, ICWST 2018, Implementation of Wood Science in Woodworking Sector, Zagreb, Croatia, 6-7 December 2018; pp. 163-171.

65. Wojnowska, M.; Smardzewski, J. Sztywność i wytrzymałość warstwowych płyt komórkowych z auksetycznym, papierowym rdzeniem. In Proceedings of the Zagadnienia Aktual. Poruszane Przez Młodych Nauk. 13, Kraków, Poland, 14-21 April 2018; pp. 134-138.

66. Peliński, K.; Wojnowska, M.; Maslej, M.; Słonina, M.; Smardzewski, J. Modeling of density of periodic structures cores of honeycomb panels. In Proceedings of the XXVIIIth International Conference Research for Furniture Industry, Poznań, Poland, 21-22 September 2017; pp. 127-137.

67. Stavroulakis, G.E. Auxetic behaviour: Appearance and engineering applications. Phys. Status Solidi Basic Res. 2005, 242, 710-720. [CrossRef]

68. Pasternak, E.; Dyskin, A.V. Materials and structures with macroscopic negative Poisson's ratio. Int. J. Eng. Sci. 2012, 52, 103-114. [CrossRef]

69. Critchley, R.; Corni, I.; Wharton, J.A.; Walsh, F.C.; Wood, R.J.K.; Stokes, K.R. A review of the manufacture, mechanical properties and potential applications of auxetic foams. Phys. Status Solidi Basic Res. 2013, 250, 1963-1982. [CrossRef]

70. Wan, H.; Ohtaki, H.; Kotosaka, S.; Hu, G. A study of negative Poisson's ratios in auxetic honeycombs based on a large deflection model. Eur. J. Mech. A/Solids 2004, 23, 95-106. [CrossRef]

71. Donescu, S.; Chiroiu, V.; Munteanu, L. On the Young's modulus of a auxetic composite structure. Mech. Res. Commun. 2009, 36, 294-301. [CrossRef]

72. Mukhopadhyay, T.; Adhikari, S. Effective in-plane elastic properties of auxetic honeycombs with spatial irregularity. Mech. Mater. 2016, 95, 204-222. [CrossRef]

73. Yang, L.; Harrysson, O.; West, H.; Cormier, D. Mechanical properties of 3D re-entrant honeycomb auxetic structures realized via additive manufacturing. Int. J. Solids Struct. 2015, 69-70, 475-490. [CrossRef]

74. Sun, Y.; Pugno, N.M. In plane stiffness of multifunctional hierarchical honeycombs with negative Poisson's ratio sub-structures. Compos. Struct. 2013, 106, 681-689. [CrossRef]

75. Smardzewski, J. Elastic properties of cellular wood panels with hexagonal and auxetic cores. Holzforschung 2013, 67, 87-92. [CrossRef]

76. Pelinski, K.; Smardzewski, J. Bending behavior of lightweight wood-based sandwich beams with auxetic cellular core. Polymers 2020, 12, 15. [CrossRef]

77. Smardzewski, J.; Wojciechowski, K.W.; Poźniak, A. Auxetic Lattice Truss Cores Fabricated of LayWood. BioResources 2018, 13, 8823-8838. [CrossRef]

78. Joscak, P.; Krasula, P.; Vimpel, P. Strength properties of corner joints and extending joints on honeycomb boards. Ann. Wars. Univ. Life Sci. SGGW. For. Wood Technol. 2014, 87, 97-104.

79. Masters, I.G.; Evans, K.E. Models for the elastic deformation of honeycombs. Compos. Struct. 1996, 35, 403-422. [CrossRef]

80. Grima, J.N.; Attard, D.; Ellul, B.; Gatt, R. An improved analytical model for the elastic constants of auxetic and conventional hexagonal honeycombs. Cell. Polym. 2011, 30, 287-310. [CrossRef]

81. Shokri Rad, M.; Prawoto, Y.; Ahmad, Z. Analytical solution and finite element approach to the 3D re-entrant structures of auxetic materials. Mech. Mater. 2014, 74, 76-87. [CrossRef]

82. Liu, Y.; Hu, H. A review on auxetic structures and polymeric materials. Sci. Res. Essays 2010, 5, $1052-1063$.

83. Polish Committee for Standardization. PN EN 310: 1994. Wood-Based Panels_Determination of Modulus of Elasticity in Bending and of Bending Strength; Polish Committee for Standardization: Warszawa, Poland, 1994.

84. International Organization for Standardization. ISO 1924-2 Paper and Board: Determination of Tensile Properties. Part 2: Constant Rate of Elongation Method (20 mm/min); International Organization for Standardization: Geneva, Switzerland, 2008. 
85. Polish Committee for Standardization. PN EN 322: 1999. Wood-Based Panels_Determination of Moisture Content; Polish Committee for Standardization: Warszawa, Poland, 1999.

86. International Organization for Standardization. ISO 536 Paper and Board-Determination of Grammage; International Organization for Standardization: Geneva, Switzerland, 2019.

87. International Organization for Standardization. ISO 534 Paper and Board-Determination of Thickness, Density and Specific Volume; International Organization for Standardization: Geneva, Switzerland, 2011.

88. Majewski, A.; Smardzewski, J.; Krystofiak, T. Mechanical properties of multi-layered panels with double-arrow shaped auxetic cores. In Proceedings of the The XXIXTH International Conference Research for Furniture Industry, Ankara, Turkey, 19-20 September 2019; pp. 1-18.

(C) 2020 by the authors. Licensee MDPI, Basel, Switzerland. This article is an open access article distributed under the terms and conditions of the Creative Commons Attribution (CC BY) license (http://creativecommons.org/licenses/by/4.0/). 